\title{
Bite Cell to Erythrocyte Ratio Measurement
}

National Cancer Institute

\section{Source}

National Cancer Institute. Bite Cell to Erythrocyte Ratio Measurement. NCI Thesaurus.

Code C74634.

The determination of the ratio of bite cells compared to erythrocytes present in a sample. The measurement may be expressed as a ratio or percentage. 